\title{
Seasonal variation in mortality in The Netherlands
}

\author{
J P Mackenbach, A E Kunst, C W N Looman
}

\begin{abstract}
Study objective-The aim was to describe the pattern of seasonal variation in all cause mortality in The Netherlands, and to analyse the contribution of specific causes of death to the winter excess of all cause mortality.

Design-Daily numbers of deaths in The Netherlands, by cause, were obtained for the period 1979-1987. Patterns of variation were analysed using Poisson regression. The model related the observed number of deaths to (1) the number expected for that day on the basis of person-days at risk by age and sex, (2) secular trend, and (3) first and higher order cosine terms where appropriate.
\end{abstract}

Main results-All cause mortality has a bimodal peak in the first months of the year. After that it declines to reach a plateau in late spring. Mortality is lowest at the end of August, after which it rises steeply again. The winter excess of all cause mortality is primarily due to cardiovascular diseases $(66 \%)$ and respiratory conditions (13\%). Cardiovascular mortality peaks before respiratory mortality, suggesting different lag times in the effects of winter. There was an episode of exceptionally high mortality (above the normal winter excess) in early 1986, which was primarily due to cardiovascular diseases (39\%) and respiratory conditions ( $25 \%$ ). This episode was probably caused by a severe influenza epidemic, and was not followed by a compensatory lowering of mortality.

Conclusions-The pattern of variation of mortality within the year suggests that it is not based on a simple relationship with climatological circumstances, because the latter fluctuate according to a less complex pattern. Cause specific data suggest an instantaneous effect of "winter" on the cardiovascular system, and a delayed effect mediated by respiratory infections.

Department of Public Health and Social Medicine, Erasmus Mniversity Medical School, PO Box 1738 3000 DR Rotterdam, The Netherlands J P Mackenbach A E Kunst C W N Looman

Correspondence to: Dr Mackenbach

Accepted for publication June 1991 considerably during the first half of this century (due to rapid declines in mortality from gastrointestinal infections, which used to cause summer
In countries with a "modern" mortality regime other times of the year ${ }^{1}$ e winter months than at and Wales has shown that there has been an excess ity in the first quarter of the year the start of death registration. This excess epidemics). Since 1950 the winter excess in mortality has diminished again, but it is still substantial. $^{2}$

We report on an analysis of seasonal variation in mortality in The Netherlands in a recent time period (1979-1987). Using data on mortality by day and cause of death we have addressed the following questions: (1) What is the pattern of variation (functional form, timing, amplitude) of all cause mortality within the year? and (2) What is the contribution of specific causes of death to the winter excess of total mortality, and what do cause specific patterns suggest about backgrounds of the variation in all cause mortality?

We shall also pay attention to deviations from the usual pattern in this sequence of nine years, because years with exceptional patterns of variation may provide important suggestions about possible backgrounds.

The analysis to be reported here forms the first part of a larger study of seasonal variation in mortality in The Netherlands, commissioned after an episode of exceptionally high mortality rates in the first months of 1986 . In later communications we will report on analyses of the association between mortality and a number of explanatory variables.

\section{Methods}

Numbers of deaths, by day on which the death occurred (from 1 January 1979 to 31 December 1987) and by cause of death (according to the abridged mortality (AM) list of the International classification of diseases), were supplied by the Netherlands Central Bureau of Statistics. Table I presents some basic information about these causes of death. Some uncommon causes of death have been grouped together, as well as a number of narrowly related causes. Cardiovascular diseases are by far the largest group of causes of death in The Netherlands $(44 \%$ of total mortality), followed by malignant neoplasms $(27 \%)$, respiratory diseases $(5 \%)$, and external causes $(5 \%)$. The standard deviation of the daily number of deaths is mostly much larger than the standard deviation under the assumption of a Poisson distribution (this standard deviation is approximately equal to the square root of the observed number of deaths). This suggests that the daily variation is indeed much larger than expected on the basis of chance fluctuations alone.

Population numbers by age (in five year age groups) and sex for the first of January of each year were available from the population register. Linear interpolation provided estimates of person-days at risk, by age and sex, for each calendar day in the period considered. For the age 
group $<1$ year we adjusted the person-days obtained with the interpolation method for the seasonal variation in the number of births.

As daily numbers of deaths were not available by age and sex, we had to resort to a form of indirect standardisation, using person-days at risk by age and sex and average daily mortality rates by age and sex for the whole period (calculated from published data) to calculate "expected" numbers of deaths for each calendar day.

In order to summarise the patterns of variation in mortality we performed a Poisson regression analysis. ${ }^{3}$ We started with a simple model in which the observed numbers of deaths $(y)$ were related to the expected numbers of deaths (see above) and a linear function of time to allow for secular trends. We then proceeded by adding a simple periodic function to descibe the pattern of variation within the year. ${ }^{4}$ The regression equation for this model is:

Table I Causes of death included in the analysis. The Netherlands, 1979-1987

\begin{tabular}{|c|c|c|c|}
\hline Causes of death & $\begin{array}{l}\text { Code } \\
\text { number } \\
\text { (ICD-AM) }\end{array}$ & $\begin{array}{l}\text { Average } \\
\text { number } \\
\text { of deaths } \\
\text { per day }\end{array}$ & $\begin{array}{l}\text { Standard } \\
\text { deviation }\end{array}$ \\
\hline $\begin{array}{l}\text { Intestinal infections } \\
\text { Tuberculosis } \\
\text { Meningitis } \\
\text { Septicaemia } \\
\text { Other infectious diseases }\end{array}$ & $\begin{array}{l}01 \\
02,03 \\
24 \\
07 \\
04-06,08-11\end{array}$ & $\begin{array}{l}0.12 \\
0.45 \\
0 \cdot 18 \\
0.57 \\
0.59\end{array}$ & $\begin{array}{l}0.35 \\
0.66 \\
0 \cdot 42 \\
0 \cdot 77 \\
0.76\end{array}$ \\
\hline $\begin{array}{l}\text { Stomach cancer } \\
\text { Colorectal cancer } \\
\text { Lung cancer } \\
\text { Breast cancer } \\
\text { Other cancers }\end{array}$ & $\begin{array}{l}12 \\
13,14 \\
15 \\
16 \\
17-19\end{array}$ & $\begin{array}{r}6 \cdot 84 \\
10 \cdot 48 \\
21 \cdot 92 \\
7 \cdot 98 \\
41 \cdot 46\end{array}$ & $\begin{array}{l}2 \cdot 67 \\
3 \cdot 28 \\
4 \cdot 93 \\
2 \cdot 87 \\
7 \cdot 16\end{array}$ \\
\hline Diabetes mellitus & 20 & $5 \cdot 38$ & $3 \cdot 41$ \\
\hline $\begin{array}{l}\text { Ischaemic heart disease } \\
\text { Cerebrovascular disease } \\
\text { Other cardiovascular diseases }\end{array}$ & $\begin{array}{l}28,29 \\
30 \\
25-27,31,32\end{array}$ & $\begin{array}{l}68 \cdot 27 \\
32 \cdot 70 \\
42 \cdot 57\end{array}$ & $\begin{array}{r}11 \cdot 14 \\
6 \cdot 47 \\
8 \cdot 55\end{array}$ \\
\hline \multirow{2}{*}{$\begin{array}{l}\text { Pneumonia } \\
\text { Influenza } \\
\text { Chronic non-specific lung } \\
\quad \text { disease (CNSLD) }\end{array}$} & $\begin{array}{l}33 \\
34\end{array}$ & $\begin{array}{l}8 \cdot 17 \\
0.47\end{array}$ & $\begin{array}{l}3 \cdot 70 \\
1 \cdot 40\end{array}$ \\
\hline & 35 & $7 \cdot 67$ & $3 \cdot 11$ \\
\hline Nephritis, etc & 39 & $3 \cdot 22$ & 1.91 \\
\hline $\begin{array}{l}\text { Congenital anomalies } \\
\text { Perinatal conditions }\end{array}$ & $\begin{array}{l}43 \\
44,45\end{array}$ & $\begin{array}{l}2 \cdot 15 \\
1 \cdot 60\end{array}$ & $\begin{array}{l}1 \cdot 48 \\
1 \cdot 32\end{array}$ \\
\hline $\begin{array}{l}\text { Symptoms and ill defined } \\
\text { conditions } \\
\text { All other natural causes }\end{array}$ & $\begin{array}{l}46 \\
21-23,36-38, \\
40-42,47\end{array}$ & $\begin{array}{l}11 \cdot 66 \\
34 \cdot 15\end{array}$ & $\begin{array}{l}5 \cdot 43 \\
7 \cdot 47\end{array}$ \\
\hline $\begin{array}{l}\text { Motor vehicle accidents } \\
\text { Accidental falls } \\
\text { Suicide } \\
\text { Other external causes }\end{array}$ & $\begin{array}{l}48,49 \\
50 \\
51 \\
52,53\end{array}$ & $\begin{array}{l}4 \cdot 58 \\
4 \cdot 38 \\
4 \cdot 33 \\
2 \cdot 86\end{array}$ & $\begin{array}{l}2 \cdot 49 \\
2 \cdot 22 \\
2 \cdot 19 \\
1 \cdot 84\end{array}$ \\
\hline Total mortality & all & $324 \cdot 7$ & $32 \cdot 86$ \\
\hline
\end{tabular}

$$
\begin{gathered}
\log \hat{y}_{d}=\log e_{d}+\beta_{1}(t-\bar{t})+\gamma_{1} \cos [(2 \pi / \\
\left.365 \cdot 25)\left(t-\tau_{1}\right)\right]
\end{gathered}
$$

in which: $\hat{y}_{d}=$ estimated number of deaths on day $d ; e_{d}=$ expected number of deaths on day $d$, calculated on the basis of average daily mortality rates by age and sex over the whole period (offset parameter); $\mathrm{t}=$ time $(\mathrm{t}=1$ for $1.1 .1979, \mathrm{t}=3287$ for 31.12.1987); $\bar{t}=$ central point of the time-axis (2.7.1983); and $\beta_{1}, \gamma_{1}$, and $\tau_{1}$ are the parameters to be estimated: $\beta_{1}$ describes linear changes of mortality over time; $\gamma_{1}$ and $\tau_{1}$ are the amplitude and acrophase (location in time of the peak) of a simple cosine function with frequency $2 \pi / 365 \cdot 25$ (one complete cycle per period of 365.25 days).

When the cosine term was statistically significant at the $5 \%$ level, we proceeded by subsequently adding cosine terms of the form $\gamma_{\mathrm{k}} \cos \left[(\mathrm{k} 2 \pi / 365 \cdot 25)\left(\mathrm{t}-\tau_{\mathrm{k}}\right)\right]$, in which $\mathrm{k}=2, \mathrm{k}=3$, etc. ${ }^{4}$ If the term with $\mathrm{k}=2$ was statistically significant, we also tried a term with $\mathrm{k}=3$, and so on until a further refinement did not prove to be significant at the 5\% level. These higher order cosine terms or trigonometric polynomials allow for the presence of additional mortality fluctuations of frequency $4 \pi / 365 \cdot 25$ (two complete cycles per year), $6 \pi / 365 \cdot 25$ (three complete cyles per year), etc. Trigonometric polynomials can describe quite complicated patterns of variation, such as bimodal distributions, differences in slope before and after the mortality peak, etc. With $k>1, \gamma_{k}$ and $\tau_{k}$ cannot directly be interpreted as amplitude and acrophase but can be used to calculate a maximum and minimum of the curve.

A period of nine years is of course rather short to establish "usual patterns of variation". In order to test the stability of the estimates based on the nine year period, we repeated the analysis by subsequently omitting each of the nine years. The results of this informal "jack knife" method indicate whether the estimates may be biased by the presence of one "exceptional" year.

The computations were performed with the GLIM computer package, ${ }^{5}$ which calculates maximum likelihood estimates for the regression parameters by using an iteratively reweighted least squares procedure. Differences in scaled deviance between models were used to test the statistical significance of added terms.

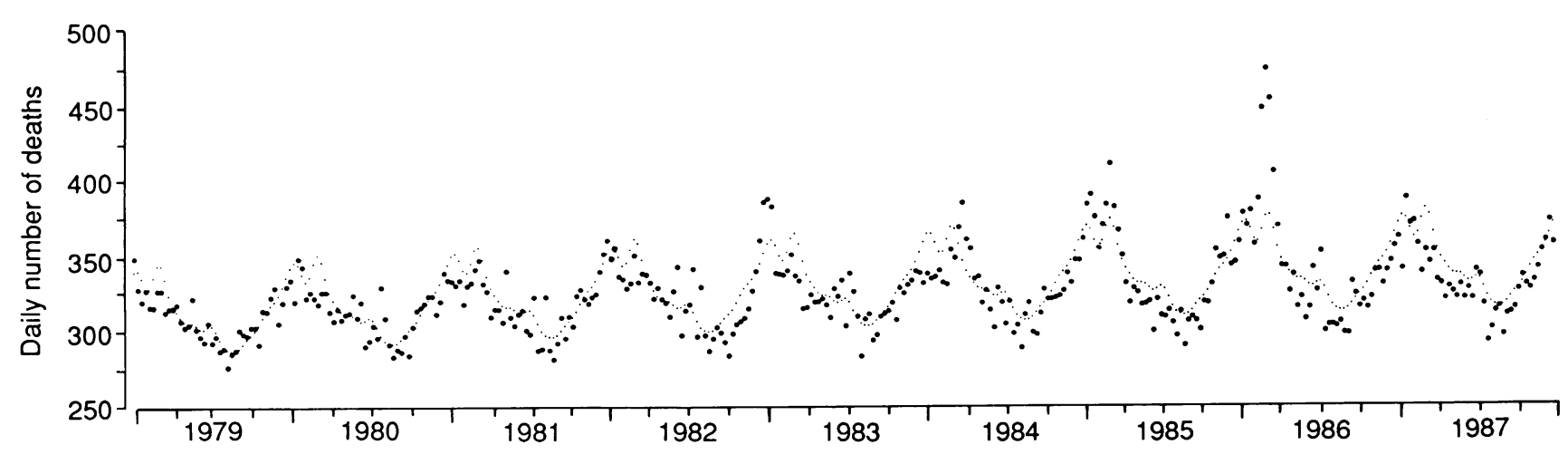

Seasonal variation in all cause mortality in The Netherlands, 1979-1987: daily numbers of deaths averaged over nine day periods. ...Observed; .... Fitted using a ninth order trigonometric polynomial model (see text) 


\section{Results}

The figure summarises the variation over time of all cause mortality. For this illustration, observed numbers of deaths have been averaged over periods of arbitrary length (nine days) to reduce random error. A slightly rising tendency can be noted; this is due to shifts in the age distribution of the population. Mortality peaks in the first quarter of the year. There is a clear suggestion of bimodality within the winter period in at least some of the years considered (1981, 1983, 1984, 1985). The height of the peaks differs substantially between the years, with record heights being attained in early 1986 . The trough is located in the third quarter of the year, with little variation in depth. The decline from winter peak to summer trough is frequently interrupted by minor peaks around the middle of the year.

Table II presents the results of a regression analysis allowing for changes in age and sex distribution of the population, secular trend, and an appropriate periodic function. For total mortality, a ninth order model is selected, including cosine terms with $\mathrm{k}=1, \mathrm{k}=2$, etc, up to $k=9$. Despite the use of higher order

Table II Results of Poisson regression of the daily number of deaths on periodic functions of time, controlling for changes in the age and sex distribution of the population and for secular trend

\begin{tabular}{|c|c|c|c|c|c|}
\hline \multirow[b]{2}{*}{ Causes of death } & \multirow[b]{2}{*}{$\begin{array}{l}\text { Order of } \\
\text { selected }^{\text {model }}\end{array}$} & \multicolumn{3}{|c|}{ Estimates according to selected model } & \multirow[b]{2}{*}{$\begin{array}{l}\text { Stability of } \\
\text { peak day } \\
\text { estimate }\end{array}$} \\
\hline & & $\begin{array}{l}\text { Peak } \\
\text { day }\end{array}$ & $\begin{array}{l}\text { Trough } \\
\text { day }\end{array}$ & $\begin{array}{l}\text { Ratio of } \\
\text { of peak and } \\
\text { trough } \\
\text { value }\end{array}$ & \\
\hline $\begin{array}{l}\text { Intestinal infections } \\
\text { Tuberculosis } \\
\text { Meningitis } \\
\text { Septicaemia } \\
\text { Other infectious diseases }\end{array}$ & $\begin{array}{l}2 \\
2 \\
1 \\
1 \\
2\end{array}$ & $\begin{array}{l}\text { Aug } 10 \\
\text { Jan } 14 \\
\text { Mar } 2 \\
\text { Apr 27 } \\
\text { Feb } 15\end{array}$ & $\begin{array}{l}\text { Nov } 29 \\
\text { Sep 24 } \\
\text { Aug } 31 \\
\text { Oct 26 } \\
\text { Oct } 28\end{array}$ & $\begin{array}{l}2.37 \\
1.59 \\
1.49 \\
1.21 \\
1.33\end{array}$ & $\begin{array}{l}\text { OK } \\
\text { OK } \\
\text { OK } \\
\text { OK } \\
\text { OK }\end{array}$ \\
\hline $\begin{array}{l}\text { Stomach cancer } \\
\text { Colorectal cancer } \\
\text { Lung cancer } \\
\text { Breast cancer } \\
\text { Other cancers }\end{array}$ & $\begin{array}{l}0 \\
0 \\
1 \\
0 \\
3\end{array}$ & $\begin{array}{l}\overline{-} \\
\bar{J} \text { Jan } 24 \\
\overline{\text { Nov }} 29\end{array}$ & $\begin{array}{l}\overline{-} \\
\overline{\text { Jul }} 25 \\
\overline{\text { May }} 17\end{array}$ & $\begin{array}{l}- \\
- \\
1.06 \\
-1.07\end{array}$ & $\begin{array}{l}\text { na } \\
\text { na } \\
\text { OK } \\
\text { na } \\
\text { excl 1987: } \\
\text { Feb 22 }\end{array}$ \\
\hline Diabetes mellitus & 1 & Feb 7 & Aug 8 & $1 \cdot 28$ & OK \\
\hline $\begin{array}{l}\text { Ischaemic heart disease } \\
\text { Cerebrovascular disease } \\
\text { Other cardiovascular diseases }\end{array}$ & $\begin{array}{l}7 \\
2 \\
4\end{array}$ & $\begin{array}{l}\operatorname{Jan} 5 \\
\operatorname{Jan} 23 \\
\text { Feb } 7\end{array}$ & $\begin{array}{l}\text { Aug } 14 \\
\text { Sep } 1 \\
\text { Aug } 27\end{array}$ & $\begin{array}{l}1.34 \\
1.25 \\
1.33\end{array}$ & $\begin{array}{l}\text { OK } \\
\text { OK } \\
\text { excl 1986: } \\
\text { Jan } 16\end{array}$ \\
\hline $\begin{array}{l}\text { Pneumonia } \\
\text { Influenza } \\
\text { Chronic non-specific lung } \\
\text { disease }\end{array}$ & $\begin{array}{l}6 \\
8 \\
6\end{array}$ & $\begin{array}{l}\text { Mar } 6 \\
\text { Mar } 6 \\
\text { Mar } 6\end{array}$ & $\begin{array}{l}\text { Sep } 1 \\
\text { Sep } 8 \\
\text { Aug } 29\end{array}$ & $\begin{array}{r}1.88 \\
73.10 \\
1.50\end{array}$ & $\begin{array}{l}\text { OK } \\
\text { OK } \\
\text { excl 1986: } \\
\text { Jan } 5\end{array}$ \\
\hline Nephritis, etc & 1 & Feb 18 & Aug 19 & $1 \cdot 30$ & OK \\
\hline Congenital anomalies & 4 & Dec 8 & Jul 31 & 1.23 & $\begin{array}{l}\text { excl 1987: } \\
\text { Mar } 10\end{array}$ \\
\hline Perinatal conditions & 0 & - & - & - & na \\
\hline $\begin{array}{l}\text { Symptoms and ill-defined } \\
\text { conditions }\end{array}$ & 8 & May 23 & Apr 20 & 1.62 & $\begin{array}{l}\text { excl 1986: } \\
\text { Oct } 17\end{array}$ \\
\hline All other natural causes & 4 & Feb 24 & Sep 23 & $1 \cdot 20$ & OK \\
\hline Motor vehicle accidents & 5 & Nov 27 & Feb 26 & $1 \cdot 39$ & $\begin{array}{l}\text { excl 1986: } \\
\text { May } 26\end{array}$ \\
\hline $\begin{array}{l}\text { Accidental falls } \\
\text { Suicide } \\
\text { Other external causes }\end{array}$ & $\begin{array}{l}2 \\
4 \\
2\end{array}$ & $\begin{array}{l}\text { Jan } 21 \\
\text { Mar } 15 \\
\text { May } 30\end{array}$ & $\begin{array}{l}\text { Sep } 12 \\
\text { Jan } 12 \\
\text { Apr } 21\end{array}$ & $\begin{array}{l}1.28 \\
1.17 \\
1.45\end{array}$ & $\begin{array}{l}\text { OK } \\
\text { OK } \\
\text { excl 1982: } \\
\text { Aug } 4\end{array}$ \\
\hline Total mortality & 9 & Mar 3 & Aug 24 & $1 \cdot 22$ & $\begin{array}{l}\text { excl 1986: } \\
\text { Jan } 8\end{array}$ \\
\hline $\begin{array}{l}\text { The model was selected using } \\
k=2 \text { etc. were subsequently adde } \\
\text { a term with } k=1 \text { was not statistic } \\
\text { gccurring in this table, includes } \\
\text { 'The stability of the peak day esti } \\
\text { which one of the nine years was } \\
>20 \text { days before or after the est } \\
\text { latter estimate "OK". If the stak } \\
\text { the results of the analysis which }\end{array}$ & $\begin{array}{l}\text { rward ste } \\
\text { l zero orde } \\
\text { significan } \\
\text { sine terms } \\
\text { te was test } \\
\text { tted. If no } \\
\text { tte presen } \\
\text { y was not } \\
\text { oduced th }\end{array}$ & $\begin{array}{l}\text { ping proc } \\
\text { r model do } \\
\text { at } 5 \% \text { lev } \\
\text { with } k=1 \\
\text { d by perfo } \\
\text { ne of these } \\
\text { ed in this } \\
\text { satisfactor } \\
\text { largest } d\end{array}$ & $\begin{array}{l}\text { ure, in wh } \\
\text { not includ } \\
\text { A ninth or } \\
=2 \text { etc. } u \\
\text { ing nine ac } \\
\text { alyses res } \\
\text { ole, we cor } \\
\text { ccording t }\end{array}$ & $\begin{array}{l}\text { h cosine term } \\
\text { a cosine term } \\
\text { er model, the } \mathrm{h} \\
\text { to } \mathrm{k}=9 \text {. } \\
\text { litional analys } \\
\text { lted in a peak } \\
\text { idered the sta } \\
\text { this measure, } \\
\text { = not applice }\end{array}$ & $\begin{array}{l}\text { s with } \mathrm{k}=1 \text {, } \\
\text { because even } \\
\text { highest order } \\
\text { es, in each of } \\
\text { day estimate } \\
\text { ability of the } \\
\text { we mention } \\
\text { able. }\end{array}$ \\
\hline
\end{tabular}

trigonometric polynomials, the pattern is not particularly complicated. The figure contains the fitted values (averaged over nine day periods) using this selected model, in the form of small dots. After its late summer trough mortality risk rises steeply to a first peak in early January. Shortly after this first peak a second, slightly higher, peak follows in early March. The decline which follows is interrupted by a plateau in May and June. The ratio of the peak and trough values, a transformation of the amplitude of the wave function which enables us to make comparisons between causes of death, is 1.22 for total mortality.

According to the results presented in table II, the stability of the peak day estimate for this nine year period is unsatisfactory for total mortality. If one of the years (1986) is omitted, the peak day estimate changes from March 3 to January 8. Apparently, the second peak loses its predominance and the first one becomes largest.

For a small number of causes of death (stomach cancer, colorectal cancer, breast cancer, perinatal conditions) there appears to be no seasonal variation of sufficient magnitude for a simple cosine term to reach statistical significance. For the other causes there is, and sometimes of surprising magnitude: mortality due to influenza on average is more than 70 times higher at its late winter peak than in summer.

Fifteen causes of death peak in either January, February, or March. Important exceptions are intestinal infections (August), other cancers (November), symptoms and ill defined conditions (May), motor vehicle accidents (November), and other external causes (May). For some causes of death the peak estimate is unstable. In two cases (other cardiovascular diseases, chronic nonspecific lung disease) the problem is the same as with total mortality: the "exceptional" situation in 1986 has shifted the maximum from a first, "normal" peak to a second peak. In the other cases the pattern of variation is more complicated than a bimodal pattern, and the location of the maximum varies between the years.

Of the causes having their peak in January, February, or March, some peak earlier than others. The clearest contrast is between cardiovascular diseases, which normally peak in January, and pneumonia and influenza which peak in March. This suggests the possibility of a difference in lag time of the effects of "winter".

The main contributors to the winter excess of mortality are cardiovascular and respiratory diseases (table III). We used the results of the regression analysis of total mortality to pinpoint the beginning and end of the period of a winter excess in total mortality. This was defined as the period during which the fitted values calculated with the ninth order model were higher than those calculated with a model without a periodic function. This period starts at November 11 , and ends at April 14.

The average excess number of deaths is 2964 per winter period (approximately $2 \cdot 5^{\circ}$ of the yearly number of deaths in The Netherlands). Sixty six percent of these are due to cardiovascular diseases, and $13 \%$ to respiratory conditions. The contribution of these causes to the winter excess of mortality is much higher than their contribution 
Table III The contribution of selected causes of death to the winter excess in all cause mortality

Table IV The contribution of selected causes of death to the episode of exceptionally high mortality in early 1986 to year round mortality $(44 \%$ and $5 \%$ respectively). Malignant neoplasms, although accounting for $27 \%$ of year round mortality, do not contribute substantially to the winter excess in all cause mortality. Neither do external causes.

The most important deviation from the usual pattern in this nine year period is an episode of exceptionally high mortality in early 1986 (figure). If it is defined as a period of consecutive days on each of which the number of deaths exceeds the number expected on the basis of the

\begin{tabular}{lcc}
\hline & \multicolumn{2}{c}{$\begin{array}{c}\text { Extra deaths during } \\
\text { winter period }\end{array}$} \\
\cline { 2 - 3 } & \multicolumn{2}{c}{$\begin{array}{c}\text { Percentage } \\
\text { share in the } \\
\text { winter excess } \\
\text { of all cause } \\
\text { mortality }\end{array}$} \\
Cause of death & $\begin{array}{l}\text { Absolute } \\
\text { number }\end{array}$ & 0 \\
Stomach cancer & 8 & 0 \\
Colorectal cancer & 1 & 2 \\
Lung cancer & 59 & 1 \\
Breast cancer & 101 & 3 \\
Other cancers & 929 & 31 \\
Ischaemic heart disease & 403 & 14 \\
Cerebrovascular disease & 634 & 21 \\
Other cardiovascular diseases & 191 & 6 \\
Pneumonia & 70 & 2 \\
Influenza & 156 & 5 \\
Chronic non-specific lung & disease & 12 \\
All other natural causes & 366 & -1 \\
Motor vehicle accidents & -37 & 2 \\
Accidental falls & 59 & -0 \\
Suicide & -3 & -0 \\
Other external causes & -14 & 100 \\
Total mortality & 2964 &
\end{tabular}

${ }^{2}$ Deaths in excess of number expected on the basis of yearly average. Average over a period of nine years (1979-1987). Winter period=November 11-April 14 (see text for explanation).

\begin{tabular}{|c|c|c|}
\hline \multirow[b]{2}{*}{ Cause of death } & \multicolumn{2}{|c|}{$\begin{array}{l}\text { Extra deaths during } \\
\text { this episode (Feb 10-Mar 25) }\end{array}$} \\
\hline & $\begin{array}{l}\text { Absolute } \\
\text { number }\end{array}$ & $\begin{array}{l}\text { Percentage } \\
\text { share in the } \\
\text { extra deaths } \\
\text { for all cause } \\
\text { mortality }\end{array}$ \\
\hline $\begin{array}{l}\text { Stomach cancer } \\
\text { Colorectal cancer } \\
\text { Lung cancer } \\
\text { Breast cancer } \\
\text { Other cancers }\end{array}$ & $\begin{array}{r}-27 \\
14 \\
98 \\
19 \\
206\end{array}$ & $\begin{array}{r}-1 \\
0 \\
3 \\
0 \\
6\end{array}$ \\
\hline $\begin{array}{l}\text { Ischaemic heart disease } \\
\text { Cerebrovascular disease } \\
\text { Other cardiovascular } \\
\text { diseases }\end{array}$ & $\begin{array}{l}584 \\
181 \\
680\end{array}$ & $\begin{array}{r}16 \\
5 \\
18\end{array}$ \\
\hline $\begin{array}{l}\text { Pneumonia } \\
\text { Influenza } \\
\text { Chronic non-specific lung } \\
\quad \text { disease }\end{array}$ & $\begin{array}{l}423 \\
300\end{array}$ & $\begin{array}{r}11 \\
8\end{array}$ \\
\hline All other natural causes & 945 & 26 \\
\hline $\begin{array}{l}\text { Motor vehicle accidents } \\
\text { Accidental falls } \\
\text { Suicide } \\
\text { Other external causes }\end{array}$ & $\begin{array}{r}-12 \\
31 \\
16 \\
8\end{array}$ & $\begin{array}{r}-0 \\
1 \\
0 \\
0\end{array}$ \\
\hline Total mortality & 3700 & 100 \\
\hline
\end{tabular}

Table V Quarterly number of deaths, 1979-1987

\begin{tabular}{llllll}
\hline Year & fan-Mar & Apr-fun & ful-Sep & Oct-Dec & Total \\
\hline 1979 & 29373 & 27875 & 26473 & 28847 & 112568 \\
1980 & 30061 & 28042 & 26919 & 29302 & 114324 \\
1981 & 30145 & 28221 & 27077 & 30118 & 115561 \\
1982 & 30750 & 29073 & 27608 & 29876 & 117305 \\
1983 & 31056 & 28956 & 27964 & 29873 & 117849 \\
1984 & 31812 & 29724 & 27735 & 30463 & 119734 \\
1985 & 34314 & 28979 & 27671 & 31677 & 122641 \\
1986 & 36469 & 29769 & 28228 & 30808 & 125274 \\
1987 & 32384 & 29699 & 28280 & 31724 & 122087 \\
\hline
\end{tabular}

selected (ninth order) model, this episode lasted from February 10 to March 25. It is perhaps to be interpreted as a larger than usual second peak in the normal winter excess.

The total number of deaths in this period was $24 \%$ (or 3700 in absolute terms) higher than the numbers expected. Table IV shows the contribution of specific causes of death to this increase in all cause mortality. The main contributors are cardiovascular diseases $(39 \%)$ and respiratory conditions $(25 \%)$. A comparison with table III shows that the contribution of respiratory conditions, especially that of pneumonia and influenza, is much larger than what one would expect if this episode simply represented the normal winter excess on a larger scale.

The high mortality rates in the first quarter of 1986 were not followed by lower than normal mortality rates later in the same year (table V). The numbers of deaths in the second, third, and fourth quarters of 1986 were not lower than expected on the basis of the numbers observed in other years. Also, the total number of deaths in 1986 is clearly higher than expected. To a lesser extent this also applies to (the first quarter of) 1985. The absence of a compensatory lowering of mortality suggests that the extra deaths in February and March 1986 did not only, or even primarily, occur among those who were going to die soon anyway.

\section{Discussion}

Our results show that variation of mortality within the year is not negligible in The Netherlands. At its winter peak, mortality is on average $22 \%$ higher than at its summer trough, and the average winter excess accounts for $2.5 \%$ of year round mortality. For some specific causes of death, for example cardiovascular diseases and respiratory conditions, these figures are considerably higher. Although this underlines the potential gains in public health after a (further) elimination of seasonal variation in mortality, it is important to note that the variation in The Netherlands is small by international standards. In a comparison of 18 European countries The Netherlands, Western Germany, and the Scandinavian countries were shown to have a much smaller winter excess of mortality than the United Kingdom, Ireland, Belgium, and a number of Mediterranean countries. ${ }^{6}$

The variation of mortality within the year in The Netherlands represents an interesting pattern, with a steep rise from the end of August to the beginning of January, a second peak in early March, and a decrease starting in March which is interrupted by a plateau in late spring. To our knowledge, no equally detailed descriptions of the situation in other countries have been made, with the exception of Finland. ${ }^{7}$ The pattern which we observe contains an important clue to the explanation of seasonal variation in mortality because temperature, which has often been shown to be associated with mortality ${ }^{8-10}$ has a much more simple pattern of variation in The Netherlands. Maximum daily temperature peaks around the first of August, declines regularly to reach its lowest value six months later around the first of February, and then rises regularly again. 
(An instantaneous effect of) temperature thus cannot be the only factor.

The fact that the first winter peak is followed by a second one is not what one would expect on the basis of the general improvement of climatological circumstances during the first months of the year. This suggests that the effect of "winter" may consist of a more or less instantaneous effect and a more delayed effect. Several hypotheses could be formulated on the nature of such a delayed effect. Thus many effects of winter on behaviour (eg, hours spent indoors) or food intake (eg, fruit) probably peak after the lowest temperature values; and the same may be true for the effects on physiological or psychological (eg, depressiveness) condition.

Most causes of death also display a winter excess. Mortality due to cardiovascular diseases, which forms the largest contributor to the winter excess of total mortality, peaks at about the same moment as maximum temperature reaches its trough. Variation in mortality from these causes of death has frequently been found to be related to variation in temperature. ${ }^{8-10}$ Possible mechanisms accounting for this association include the effects of thermoregulatory responses on arterial pressure and the risk of thrombosis (through increased blood platelets, red cell counts, and blood viscosity). ${ }^{11} 12$

Mortality due to pneumonia and influenza peaks in early March. This reflects the responsiveness of these causes of death to influenza epidemics (and maybe to other respiratory infections), which happen to occur mostly in February or March in The Netherlands. This is of course not by chance alone: conditions for the spread of these epidemics are obviously more favourable in these months than at other times of the year. The delayed effects of winter mentioned above (eg, hours spent indoors, fruit intake, general physiological condition) may be involved here. At the same time, influenza epidemics also contribute to increased rates of cardiovascular mortality in late winter.

Mortality due to malignant neoplasms does not show a marked seasonal variation. This is remarkable because it shows that the increased mortality in winter is not a generalised phenomenon striking all those whose health is compromised. It appears to be caused by more specific mechanisms.

The importance of influenza is also apparent from its contribution to an episode of exceptionally high mortality in February/March 1986. The influenza surveillance system of The Netherlands registered a very high incidence of influenza in this period. ${ }^{13}$ Although mortality due to influenza (as a registered underlying cause of death) forms only $8 \%$ of this mortality increase, it is well known that influenza also contributes to the death of people with other underlying conditions, especially chronic cardiovascular and respiratory diseases.

Analyses from the United Kingdom have shown that each influenza death was associated with 3.6 excess deaths (due to all causes including influenza) in 1949-1985. ${ }^{14}$ There appears to have been a rise in the total number of excess deaths per influenza death over this period, and during a recent epidemic in the winter of $1989 / 1990$ a ratio of 10:1 was found. ${ }^{15}$ On the basis of table IV we would calculate a ratio of 12:1 (3700:300) for the 1986 epidemic in The Netherlands.

The high mortality rates during this epidemic were not followed by a compensatory lowering of mortality later in the same year. It is clearly not those who were already terminally ill who were killed by this epidemic. This again stresses the importance of improving vaccination strategies in The Netherlands, which are rather inadequate at this moment. ${ }^{16}$

This study was supported financially by the Ministry of Welfare, Public Health and Culture, Rijswijk, The Netherlands.

1 Sakamoto-Momiyama $\mathbf{M}$. Changes in the seasonality of human mortality: a medico-geographical study. Soc $S c i$ Med 1978; 12: 29-42.

2 McDowall M. Long term trends in seasonal mortality. Popul Trends 1981; 26: 16-19.

3 Frome EL, Checkoway $\mathrm{H}$. Use of Poisson regression model in estimating incidence rates and ratios. Am $\mathcal{f}$ Epidmiol 1985; 21: 309-23.

4 Batschelet E. Circular statistics in biology. London: Academic Press, 1981

5 Baker RJ, Nelder JA. GLIM manual (release 3). Oxford: Numerical Algorithms Group, 1987.

6 McKee CM. Deaths in winter: can Britain learn from Europe? Eur $f$ Epidemiol 1989; 5: 178-82.

7 Näyhä S., Short and medium-term variations in mortality in Finland. Scand $\mathcal{F}$ Soc Med 1980; suppl 21: 1-101.

8 Finland. Scand F Soc Med 1980; suppl 21: 1-101. Bainton D, Moore F, Sweetnam P. Temperature and deaths
from ischaemic heart disease. Br $\mathcal{F}$ Prev Soc Med 1977; 31: from is

9 Rose G. Cold weather and ischaemic heart disease. $B r f$ Prev Soc Med 1966; 20: 97-100.

10 Rogot E, Padgett SJ. Associations of coronary and stroke mortality with temperature and snowfall in selected areas of the United States, 1962-1966. Am $\mathcal{F}$ Epidemiol 1976; 103: 565-75

11 Keatinge E, Coleshaw SRK, Cotter F, Mattock M, Murphy $M$, Chelliah $R$. Increases in platelet and red cell counts, blood viscosity, and arterial pressure during mild surface cooling. $B M \mathcal{Y}$ 1984; 289: 1405-8.

12 Anonymous. Deaths in winter (editorial). Lancet 1985; ii: 987-8.

13 Bartelds AIM. Continue morbiditeitsregistratie peilstations Nederland. Utrecht: NIVEL, several years.

14 Curwen $M$, Devis $T$. Winter mortality, temperature and influenza: has the relationship changed in recent years? Popul Trends 1984; 54: 17-20.

15 Curwen M, Dunnell K, Ashley J. Hidden influenza deaths: 1989-90. Popul Trends 1990; 61: 31-3.
.

16 Veen WA van. Influenza: how effective is vaccination policy (in Dutch)? Huisarts Wet 1990; 33: 415-6. 